\title{
ON THE SITUATION IN PALESTINE AND THE WAR CRIME OF TRANSFER OF CIVILIANS INTO OCCUPIED TERRITORY
}

\begin{abstract}
This paper considers the war crime at Article 8(2)(b)(viii) of the Rome Statute, 'the transfer, directly or indirectly, by the Occupying Power of parts of its own civilian population into the territory it occupies', by addressing the doctrinal elements of the provision in light of the impact which the practice of transfer of Israeli civilians into occupied territory has had on the application of the rule of international law to the broader situation in Palestine. The provision is distinct among war crimes within the Court's jurisdiction as it refers to the activity of a state - the occupying power - in addition to that of the individual perpetrator. This feature reflects the structural issues that the provision was designed to address, and emphasizes that its purpose is not so much to confront direct physical violence, but rather to prevent colonial practices. Despite the political significance of the underlying conduct there has been comparatively little analysis of the war crime itself. Following an overview of how Israel's transfer of civilians into occupied territory challenges international law's distinction between civilian and combatant and has given rise to the charge of apartheid, the paper considers the drafting history of Article 8(2)(b)(viii) of the Rome Statute, reflecting on the provision's unusual construction, before reviewing Israel's state responsibility for unlawful transfer, and considering the temporal jurisdiction of the ICC and the nature of continuing and continuous crimes.
\end{abstract}

\section{INTRODUCTION}

The war crime set forth at Article 8(2)(b)(viii) of the Rome Statute as, 'the transfer, directly or indirectly, by the Occupying Power of parts of its own civilian population into the territory it occupies', and the rule at Article 49(6) of the Fourth Geneva Convention from which it is derived, that 'States may not deport or transfer parts of their own civilian population into a territory they occupy', are marked by

\footnotetext{
* Senior Lecturer in Law, School of Law, Politics and Sociology, University of Sussex, Brighton, UK. E-mail: M.G.Kearney@sussex.ac.uk
} 
several characteristics distinguishing them from the corpus of rules and crimes with which they are categorized. In particular, the war crime refers to the activity of the state - the occupying power - in addition to that of an individual perpetrator, a detail emphasizing that its purpose is not merely to confront direct physical force, but also to oppose colonialism and its attendant structure of violence. This décalage between the war crime and the other provisions of Article 8 is evident in the claim that since not explicitly relating to 'atrocity', the conduct prohibited is not serious enough to warrant labelling and proscription as a war crime. In 1998, explaining its refusal to vote in favour of adoption of the Rome Statute due to the inclusion of Article 8(2)(b)(viii), Israel's delegate asked: 'can it really be held that such an action as that listed in Article 8 above really ranks among the most heinous and serious war crimes, especially as compared to the other, genuinely heinous ones listed in Article 8? ${ }^{1}$

Although an isolated position then, the question requires some attention since there is a broader unease with how the thrust of international law discourse can appear to be locked into ad hoc responses to crisis and to 'excessive' or 'heinous' violations, while reluctant to confront the political and cultural structures which undergird the broader reality of perpetual war. ${ }^{2}$ That international criminal law is alert to the administrative and structural elements of oppression has been evident since the prosecution of serious violations of human rights as the crime against humanity of persecution by the post-Second World War tribunals. ${ }^{3}$ The rationale for criminalizing apartheid in the 1973 Apartheid Convention ${ }^{4}$ was not to respond to atrocity, but to condemn and confront a racist system of administrative and structural domination. A similar approach can be seen in the International Criminal Tribunal for the Former $\mathrm{Yu}$ goslavia's affirmation that the crime of persecution can encompass 'acts which, although not in and of themselves inhumane, are con-

\footnotetext{
${ }^{1}$ Statement by Eli Nathan, Head of the Delegation of Israel (17 July 1998), available at https://www.legal-tools.org/doc/1232ae/; A/CONF.183/SR.9, § 33 (17 July 1998).

2 Hilary Charlesworth, 'International Law: A Discipline of Crisis' 65 Modern Law Review 3 (2002) 377; Samuel Moyn, 'Civil Liberties and Endless War' \& David Cole, 'A Defense of Civil Libertarianism' Dissent Magazine (Fall 2015).

${ }^{3}$ Kevin Jon Heller The Nuremberg Military Tribunals and the Origins of International Criminal Law (Oxford University Press, 2011) Ch 10.

${ }^{4}$ International Convention on the Suppression and Punishment of the Crime of Apartheid 1973, UNTS Vol 1015.
} 
sidered inhumane because of the discriminatory grounds on which they are taken'. 5 The impetus towards advancing the application of international criminal law beyond atrocity is clearly perceived in contemporary analyses of poverty, ${ }^{6}$ discrimination, ${ }^{7}$ asylum status, ${ }^{8}$ and hate speech. ${ }^{9}$

A particular, contextual, characteristic of the war crime as applied to the situation in Palestine is the rarity with which political discourse around Israel's settlement policy acknowledges its criminal nature. Addressing the notion of 'human shields' in the context of colonial rule and of Israeli military policy, Judith Butler cautions that 'To assume 'that a 'war crime' is easily recognised, and that there will be general consensus that one has been committed', is merely a wager. ${ }^{10}$ While the international community has been consistent in reaffirming that Israel's settlement policy is unlawful, such statements appear in abstracto, and there remains a broad refusal to recognize and to condemn the transfer of Israeli civilians into occupied territory as criminal activity for which individuals must bear responsibility.

Contrary to the 'unimaginable atrocities' of the Rome Statute's Preamble, the transfer of Israeli civilians into occupied territory has, for a prolonged period, been an overt and organised state policy, executed on a large scale and in a systematic manner, such that it is a defining feature of the military occupation of Palestinian and Syrian territory. Beyond the civilian and combatant statuses definitive of the law of armed conflict, a significant section of Israel's settler population may be more appropriately categorised as commuters, such is the extent to which Israel's imposition of 'facts on the ground' has incorporated the settlement population and infrastructure into the state of Israel. Bearing in mind Kamari Maxine Clarke's observation that

\footnotetext{
${ }^{5}$ Trial Judgment, Prosecutor v Tadić, 7 May 1997, IT-94-1-T, §715.

${ }^{6}$ Gwilym David Blunt, 'Is Global Poverty A Crime Against Humanity?' 7 International Theory 3 (2015) 539-571.

${ }^{7}$ Ruby Axelson, 'State-Sponsored Hatred and Persecution on the Grounds of Sexual Orientation: The Role of International Criminal Law' in Schweppe \& Walters (eds.), The Globalisation of Hate: Internationalising Hate Crime? (Oxford University Press, 2016) at 277.

${ }^{8}$ Ioannis Kalpouzos \& Itamar Mann, 'Banal Crimes Against Humanity: The Case of Asylum Seekers in Greece' 16 Melbourne Journal of International Law 21 (2015).

${ }^{9}$ Wibke K. Timmermann, Incitement in International Law (Routledge, 2014); Richard A. Wilson, 'Inciting Genocide with Words' 36 Michigan Journal of International Law 1 (2015) 277.

${ }^{10}$ Judith Butler, 'Human Shields' 3 London Review of International Law 2 (2015) 233.
} 
continuing violations such as colonialism or apartheid, since they challenge strict notions of legal time, "present us with less stable questions of perpetratorhood and create multivalent legal dilemmas [involving] questions of jurisdiction, admissibility and evidence', ${ }^{11}$ it will be demonstrated that the war crime of transfer of civilians into occupied territory, while lacking significant precedential guidance, and to a significant extent obscured by the need to respond also to direct and massive physical violence, remains a war crime. It addresses, with adequate clarity and certainty, a clear and specific criminal conduct which continues to be pursued as a matter of systematic public policy.

Following an overview of how Israel's transfer of civilians into occupied territory undermines international law's distinction between civilian and combatant and has given rise to the charge of apartheid, the paper considers the drafting history of Article 8(2)(b)(viii) of the Rome Statute, reflecting on the provision's unusual construction, before reviewing Israel's state responsibility for unlawful transfer, and then considering the temporal jurisdiction of the ICC and the nature of continuing and continuous crimes.

\section{TRANSFER WITH IMPUNITY}

Since 1967 Israeli governments have justified the transfer of parts of their civilian population into occupied territory by reference to a combination of strategic/military and religious/nationalistic goals. ${ }^{12}$ The Israeli High Court, having chosen not to acknowledge the applicability of Article 49(6) of the Fourth Geneva Convention, established the legalistic basis by which land in occupied territory was to be seized for the construction of settlements in the Beth El case of 1978. ${ }^{13}$ The Court predicated its approval of construction of civilian settlements on the ability of the military commander to demonstrate that the settlement would serve a verifiable strategic military function. By this method, as noted by David Kretzmer, the Court's view on 'the security function of civilian settlement [...] paves the way for actions that are not compatible with the occupying power's fundamental

${ }^{11}$ Kamari Maxine Clarke, 'Refiguring the Perpetrator: Culpability, History and International Criminal Law's Impunity Gap' 19 International Journal of Human Rights 5 (2015) 592-614, 596-597; Lorenzo Veracini, 'Introducing' 1 Settler Colonial Studies 1 (2011) 3.

\footnotetext{
${ }^{12}$ David Kretzmer, The Occupation of Justice (SUNY, 2002) 76.

${ }^{13}$ Ayyub v. Minister of Defence, 33(2) PD, p. 113, 1978.
} 
duty not to use the occupation as a means of acquiring territory by use of force. ${ }^{14}$

According to the UN's Office for the Coordination of Humanitarian Affairs, since 1967 Israel has officially established approximately 150 settlements in the occupied Palestinian territory, in addition to some 100 'outposts' erected by Israeli civilians without formal authorization. As of 2011 the Israeli civilian population in occupied Palestinian territory was estimated at 520,000, while some $43 \%$ of West Bank territory was allocated to settlement municipal councils. ${ }^{15}$

While sustained violence and the denial of the Palestinian right to self-determination are clear consequences of the settlement policy, ${ }^{16}$ in the context of such figures, the prolonged nature of the occupation, and Israel's claims to have annexed occupied territory, two additional consequences necessitate some comment.

The first relates to the increasing currency attached to claims that the system of segregation between Israeli civilians in occupied territory - the settlers - and the Palestinian population - the 'protected persons' of the Geneva Conventions - constitutes apartheid. ${ }^{17}$ In 2012 the UN Committee on the Elimination of Racial Discrimination, in its Concluding Observations on Israel's periodic report, drew attention to General Recommendation 19 (1995) concerning the prohibition of all policies and practices of racial segregation and apartheid. The Committee urged Israel to take immediate measures to "prohibit and eradicate any such policies or practices which

\footnotetext{
${ }^{14}$ Kretzmer, The Occupation of Justice 83; David Kretzmer, 'The Law of Belligerent Occupation in the SUPREME Court of Israel' 94 International Review of the Red Cross 885 (2012) 213.

${ }^{15}$ UNOCHA-OPT, The Humanitarian Impact of Israeli Settlement Policies: Update December 2012.

${ }^{16}$ Legal Consequences of the Construction of a Wall in the Occupied Palestinian Territory, Advisory Opinion, ICJ Reports 2004, § 122.

${ }^{17}$ Adam Roberts, 'Prolonged Military Occupation: The Israeli-Occupied Territories Since 1967' 84 American Journal of International Law 51 (1990), at 52; D. Kretzmer, The Occupation of Justice: The Supreme Court of Israel in the Occupied Territories (New York: State University of New York Press, 2002), at 76; V. Tilley (ed.), Beyond Occupation: Apartheid, Colonialism and International Law in the Occupied Palestinian Territories (London: Pluto Press, 2012); 'Interview with Raja Shehadeh' 94 International Review of the Red Cross 885 (2012) 13, at 17; John Dugard \& John Reynolds, 'Apartheid, International Law, and the Occupied Palestinian Territory’ 24 EJIL 3 (2013) 867.
} 
severely and disproportionately affect the Palestinian population in the Occupied Palestinian Territory'. It expressed extreme concern at:

the consequences of policies and practices which amount to de facto segregation, such as the implementation by the State party in the Occupied Palestinian Territory of two entirely separate legal systems and sets of institutions for Jewish communities grouped in illegal settlements on the one hand and Palestinian populations living in Palestinian towns and villages on the other hand. ${ }^{18}$

The Human Rights Council's 2013 Fact-finding Mission Report on Israel's settlement activity, while avoiding the apartheid label, also stressed this point, reiterating that the settlements 'are established for the exclusive benefit of Israeli Jews' through a 'system of total segregation ... supported and facilitated by a strict military and law enforcement control to the detriment of the rights of the Palestinian population'. ${ }^{19}$

Beyond the use of physical force against Palestinians by Israeli state officials in maintaining this regime, there is an increasing convergence between and among sectors of the settler population and the occupying power's military/security apparatus. ${ }^{20}$ In addressing the 'correlation between the two forms of Israeli violence - institutional military violence and non-institutional civilian violence, ${ }^{21}$ Nir Gazit describes how the political and legal structures of the Israeli occupation have provided 'the necessary 'degrees of freedom', so to speak, that allow, and even support, a proliferation of settlers' violence against Palestinian civilians."22 The 2013 Mission Report had emphasized the prevalence of settler violence, frequently in the presence of Israeli police and military:

${ }^{18}$ Concluding observations of the Committee on the Elimination of Racial Discrimination: Israel. CERD/C/ISR/CO/14-16 (9 March 2012) § 24.

${ }^{19}$ Report of the independent international fact-finding mission to investigate the implications of the Israeli settlements on the civil, political, economic, social and cultural rights of the Palestinian people throughout the Occupied Palestinian Territory, including East Jerusalem, A/HRC/22/63 (7 February 2013) § 103.

${ }^{20}$ Udi Lebel, 'Settling the Military' 21 Israel Affairs (2015) 361; Ami Pedahzura \& Holly McCarthy, 'Against all odds - the paradoxical victory of the West Bank settlers: interest groups and policy enforcement' 21 Israel Affairs 3 (2015) 457.

${ }^{21}$ Nir Gazit, 'State-Sponsored Vigilantism: Jewish Settlers' Violence in the Occupied Palestinian Territories' 49 Sociology 3 (2015) 438, 447.

22 Gazit, 'State-Sponsored Vigilantism' 450. 
the identities of settlers who are responsible for violence and intimidation are known to the Israeli authorities, yet these acts continue with impunity. The Mission is led to the clear conclusion that there is institutionalised discrimination against the Palestinian people when it comes to addressing violence. The Mission believes that the motivation behind this violence and the intimidation against the Palestinians as well as their properties is to drive the local populations away from their lands and allow the settlements to expand. ${ }^{23}$

Such developments, and the challenge which the status of settlers' pose to the principle of distinction under international humanitarian law present a particular dilemma to the application and coherence of international law. Their collective presence in occupied territory is unlawful, their function at least partially military, yet as civilians, they enjoy immunity from attack, and are thus on a formally equal footing with the Palestinians whose land they have seized. International law places no restriction as to the numbers of combatants an occupying power may choose to deploy and accepts that a number of civilians will be required to support the military function of occupation forces: Geneva Convention III for example requires that certain categories of civilian are to be accorded Prisoner of War status. ${ }^{24}$ That these are exceptions to be understood restrictively is illustrated by the commentary to Article 63(1) of Additional Protocol 1 - that civil defence organisations in occupied territory 'shall not be required to give priority to the nationals or interests of that [Occupying] Power' - which notes: 'as the transfer of the Occupying Power's own civilian population into occupied territory is prohibited by the Fourth Convention, there should really only be 'military' nationals of the Occupying Power in such territory, apart perhaps from [the] exception of some civilians who had settled there before the occupation. ${ }^{25}$

In its written pleading to the International Court of Justice before the Wall Advisory Opinion, and in a rare petition for the application

${ }^{23}$ Supra note $19, \S 107$. Also, UN News Centre, 'Israeli settler violence must be prosecuted, says UN human rights chief' 1(8 March 2013); Yesh Din, The Road to Dispossession: A Case Study - The Outpost of Adei Ad (2013); B. Ravid, U.S. State Department defines settler violence as terrorism, Ha'aretz (18 August 2012); D. Byman \& N. Sachs, The Rise of Settler Terrorism: The West Bank's Other Violent Extremists, Foreign Affairs (14 August 2012); Al-Haq, Special Focus: Settler Attacks in the West Bank (22 October 2015).

${ }^{24}$ Art. 4.4; Geneva Convention relative to the Treatment of Prisoners of War, 75 UNTS 135.

${ }^{25}$ Yves Sandoz et al. (eds.), Commentary on the Additional Protocols to the Geneva Conventions (Martinus Nijhoff, 1987) at 751, § 2498. 
of humanitarian law to occupied territory, Israel reminded the Court of the civilian status of settlers and their immunity from attack: 'Even the harshest of Israel's critics have been constrained to acknowledge that such attacks are a violation of the norms of international humanitarian law and general international law and cannot be justified. $^{26}$

An example of such acknowledgement is an Amnesty International report of 2002 on the violence of the Al-Aqsa Intifada rejecting claims on the part of Palestinian armed groups that 'the prohibition on attacking civilians does not apply to settlers in the Occupied Territories because the settlements are illegal under international humanitarian law; because settlements may have military functions; and because many settlers are armed'. Condemning Palestinian attacks on settlers as crimes against humanity, Amnesty concluded that 'settlers as such are civilians, unless they are serving in the Israeli armed forces. ${ }^{27}$ While this conclusion is correct, though a contemporaneous Human Rights Watch report distinguished settlers taking a direct part in hostilities, ${ }^{28}$ the analysis acknowledged, though without further comment as to deeper problems this revealed, that: 'Although the militarization of settlements is strongest in Gaza, some of the settlements in the West Bank also have military functions. The IDF may use them as staging posts for their operations or to detain people in their custody. A large number of settlers are armed and settlers have sometimes attacked Palestinians and destroyed Palestinian houses and other property. ${ }^{29}$

In the context of a prolonged occupation, characterized by colonial settlement, the Israeli courts have set aside international humanitarian law's categorization of Palestinians in occupied territory as protected persons, prioritizing instead settlers' needs as commuters to be protected. Eyal Weizman has explained how the World Zionist Organisation, in preparing its 1983 'Masterplan for Settlement in the West Bank through the year 2010', identified that state subsidies to specific settlements would be related to economic

${ }^{26}$ Written Statement of the Government of Israel on Jurisdiction and Propriety 29 January 2004 para 3.51 .

${ }^{27}$ Amnesty International, 'Without distinction - attacks on civilians by Palestinian armed groups' (AI Index: MDE 02/003/2002, 2002) 23.

${ }^{28}$ Human Rights Watch, 'Erased In A Moment: Suicide Bombing Attacks Against Israeli Civilians' (2002) 55.

${ }^{29}$ Amnesty International, 'Without Distinction - Attacks on Civilians by Palestinian Armed Groups' (AI Index: MDE 02/003/2002, 2002) 24. 
demand such that high demand areas were those within a 'travel time of $30 \mathrm{~min}$ from the outer ring of Tel Aviv metropolitan region and about 20 min' drive from that of Jerusalem". ${ }^{30}$ This 'settlement complex', which Ariel Handel contends should not 'be construed as an aggregate of discrete gated communities linked to each other with wide roads, but as a single gated community, ${ }^{31}$ and the extent to which settlers' commute from, and transfer back into, occupied territory are normalized, is illustrated by the Israeli High Court ruling on the application of military orders prohibiting Palestinians of occupied territory from travelling on Route 443.

Giving judgment in the Abu Saifa case in 2009, the Court described Route 443 as 'a major traffic artery connecting the area of the coastal plain [Tel Aviv] and the Modi'in [settlement] bloc to the area of Jerusalem' noting its use 'for travel by residents of the Israeli settlements in the Area'. ${ }^{32}$ Harpaz and Shany have critically observed how the Court could not ignore the large number of Israelis moving in and out of the Occupied Territories on a daily basis for a variety of commercial, religious, recreational, and other reasons' and their 'increased reliance on military measures of protection in a deteriorating security environment.' The Court's 'interpretative solution' in the face of an increasing settler population was to reconfigure Regulation 43 of the 1907 Hague Regulations. By expanding the concept of security interests so to include the protection of Israelis in the Occupied Territories' the Court rendered 'the term "protected persons" introduced by Article 4 of the Fourth Geneva Convention (which explicitly excludes nationals of the Occupying Power) increasingly irrelevant. ${ }^{33}$

In light of the violence and the continued impunity by which the occupation is being pursued, the process by which the privileges of Israeli civilian settlers are being read such as to trump the rights of Palestinians as protected persons, brings to mind China Miéville's

\footnotetext{
${ }^{30}$ Eyal Weizman, Hollow Land: Israel's Architecture of Occupation (Verso, 2007) 124.

${ }^{31}$ Ariel Handel, 'Gated/gating community: the settlement complex in the West Bank' 39 Transactions of the Institute of British Geographers 4 (2014) 504, 515.

${ }^{32}$ HCJ 2150/07 Abu Safiya v. The Minister of Defense (Dec. 29, 2009) p. 28 En TN.

${ }^{33}$ Guy Harpaz \& Yuval Shany, 'The Israeli Supreme Court and the Incremental Expansion of the Scope of Discretion under Belligerent Occupation Law' 43 Israel Law Review 514 (2010) 535, 542. Valentina Azarov 'Exploiting A 'Dynamic' Interpretation? The Israeli High Court of Justice Accepts the Legality of Israel's Quarrying Activities in the Occupied Palestinian Territory', EJIL: Talk! Blog of the European Journal of International Law, 7 February 2012.
} 
damning conclusion that 'The chaotic and bloody world around us the rule of law. ${ }^{34}$ Echoing the statements made by Israel at the Rome Conference in 1998, a recent commentary denied that the transfer of Israeli civilians into occupied territory could be of significance to the International Criminal Court since the provision is a "war crime with no direct victims and the commission of which in the circumstances in question does not involve violence'. ${ }^{35}$ Eugene Kontorovich's evaluation reflects a broader strand of rhetoric capitalising upon the emergence of a Lawfare narrative, itself a reaction to Palestinian legal advocacy, ${ }^{36}$ which seeks to retool human rights so as to reconstitute Israeli settlers as victims, and the establishment of a Palestinian state or proposals to remove settlements as being tantamount to ethnic cleansing. Kontorovich for example, could go so far as to criticise the war crime for being 'a highly restrictive and xenophobic zero immigration rule'. ${ }^{37}$ In studying such developments, and the establishment of 'human rights NGOs to advocate colonisation', Perugini and Gordon observe how a convergence of settler-activism and Israeli state interests, through organisations such as Shurat HaDin and Yesha for Human Rights, has prompted the emergence of what they have termed a 'human right to dominate and to colonise'. ${ }^{38}$

\section{ARTICLE 8(2)(B)(VIII) OF THE ROME STATUTE}

The ICRC's Customary Law Study of 2005 affirmed that Rule 130, as derived from Article 49(6) of the Fourth Geneva Convention, was 'a norm of customary international law applicable in international armed conflicts', ${ }^{39}$ yet found no evidence of any relevant national

${ }^{34}$ China Miéville, 'The Commodity-Form Theory of International Law: An Introduction' in S. Marks (ed.) International Law on the Left: Re-examining Marxist Legacies (CUP, 2008) at 132.

${ }^{35}$ Eugene Kontorovich, 'When Gravity Fails: Israeli Settlements and Admissibility at the ICC' 47 Israel Law Review 3 (2014) 399.

${ }^{36}$ Michael Kearney, 'Lawfare, Legitimacy and Resistance: The Weak and the Law' 16 Palestine Yearbook of International Law (2010) 79.

${ }^{37}$ Kontorovich 'When Gravity Fails' 389.

${ }^{38}$ Nicola Perugini \& Neve Gordon, The Human Right to Dominate (OUP, 2015).

${ }^{39}$ J.M. Henckaerts \& L. Doswald-Beck (eds.), ICRC Customary International Humanitarian Law Volume I Rules (Cambridge: Cambridge University Press, 2005), at 462 . 
case law, criminal or otherwise. ${ }^{40}$ Following Palestine's initial approach to the ICC in 2009 a shift in this emphasis gradually materialized. The Report of the Human Rights Council's 2013 Factfinding Mission on Israel's settlement activity, having reference to correspondence from Palestine to the UN Secretary-General and Security Council declaring that 'Israeli settlement activities' constitute war crimes under the Rome Statute, indicated that it would apply not only the law of state responsibility but also international criminal law. ${ }^{41}$ The Report did not engage expansively with international criminal law, simply acknowledging that 'The transfer of Israeli citizens into the OPT, prohibited under international humanitarian law and international criminal law, is a central feature of Israel's practices and policies, ${ }^{42}$ and remarking that Palestinian ratification of the Rome Statute 'may lead to accountability for gross violations of human rights law and serious violations of international humanitarian law and justice for victims. ${ }^{43}$

Other than a jurisdictional hearing before the ICTY where the defence drew on Article 49(6) and Rule 130 to successfully oppose an apparent charge of a 'crime of colonisation', ${ }^{44}$ it was not until 2014 and the United Kingdom Supreme Court's judgment in Richardson and another $v$ DPP that judicial consideration, albeit brief, was given to the scope and meaning of the war crime. ${ }^{45}$ The appellants in Richardson unsuccessfully challenged convictions for aggravated trespass arising from a protest against the sale in a London shop of Ahava products manufactured at an Israeli settlement in occupied Palestinian territory. It was put to the Court that Ahava was guilty 'of aiding and abetting the transfer by the Israeli authorities of Israeli citizens to a territory (the OPT) under belligerent occupation' and that aiding and abetting such transfer was 'an act ancillary to a war crime' under the Rome Statute as incorporated into the law of England and Wales by the International Criminal Court Act 2001. While denying the application on the facts before it, the Court

\footnotetext{
${ }^{40}$ Henckaerts \& Doswald-Beck ICRC Customary International Humanitarian Law Volume I at 457.

${ }^{41}$ Supra note $19 \S 17$.

${ }^{42}$ Ibid $\S 38$.

${ }^{43}$ Ibid $\S 104$.

${ }^{44}$ Decision on Several Motions Challenging Jurisdiction, Prosecutor v Gotovina et al., 19 March 2007, IT-06-90-PT, paras 58-66.

${ }^{45}$ Richardson and another (Appellants) $v$ Director of Public Prosecutions (Respondent) [2014] UKSC $\S 8$.
} 
accepted with respect 'the war crime argument' that if a person, including the shopkeeper company, had 'aided and abetted the transfer of Israeli civilians into the OPT, it might have committed an offence against [the 2001 Act]' ${ }^{46}$

The only jurisprudence relevant to the prohibition of transfer of civilians noted in the ICRC customary law study was the condemnation by post-Second World War tribunals of 'Germanization' policies executed by the Nazis in occupied Europe. ${ }^{47}$ The indictment in the Case of the Major War Criminals before the International Military Tribunal at Nuremberg, in alleging the war crime of plunder, referred to portions of occupied territory in Eastern Europe as having been reserved 'for exclusive settlement, development, and ownership by Germans and their so-called racial brethren', while a separate count, 'Germanization of Occupied Territory', charged that 'In certain occupied territories purportedly annexed to Germany the defendants... introduced thousands of German colonists' in violation of 'the Hague Regulations, 1907, the laws and customs of war, the general principles of criminal law as derived from criminal laws of all civilized nations, the internal penal laws of the countries in which such crimes were committed and Article 6(b) of the Charter." 48 The judgments at Nuremberg and other post-war trials tended to address what would become a series of discrete international crimes as more generalized bundles of conduct, on this particular issue not leaving much specific jurisprudence of a positively precedential character. ${ }^{49}$

Pictet's Official Commentary to the Fourth Geneva Convention, as ratified by Israel in 1951 and Palestine in 2014, explains the motive for the prohibition in Article 49(6) as the prevention of a practice 'adopted during the Second World War by certain Powers, which transferred portions of their own population to occupied territory for political and racial reasons or in order, as they claimed, to colonize

\footnotetext{
${ }^{46}$ Ibid $\S 10$.
}

${ }^{47}$ J.M. Henckaerts \& L. Doswald-Beck (eds.), ICRC Customary International Humanitarian Law Volume II Practice Part 2 (Cambridge: Cambridge University Press, 2005), at 2963, 2968-2969; C. Meindersma, 'Legal Issues Surrounding Population Transfers in Conflict Situations' 41 Netherlands International Law Review 1 (1994) 31 , at 44-45.

${ }^{48}$ Trial of the Major War Criminals Before the International Military Tribunal Nuremberg 14 November 1945 - 1 October 1946, at 63-66.

${ }^{49}$ Heller, The Nuremberg Military Tribunals at 226. Separate and partly dissenting opinion of Judge Schomberg, Prosecutor v. Naletilic \& Martinovic, IT-98-34-A, 3 May 2006, paras 10-16. 
those territories. ${ }^{50}$ With the expansion of the category of Grave Breaches in Additional Protocol I of 1977, adopted by consensus, Article 85(4)(a) provided that 'when committed wilfully and in violation of the Conventions or the Protocol', the transfer by the occupying Power of parts of its own civilian population into the territory it occupies, in violation of Article 49 of Geneva Convention IV, is a Grave Breach and thus a crime subject to universal jurisdiction. The Commentary notes that the practice, is now a grave breach because of the possible consequences for the population of the territory concerned from a humanitarian point of view. ${ }^{51}$ Israel has not ratified the Additional Protocol while Palestine ratified in 2014.

Bothe et al's commentary on the Additional Protocols points out that events in the Middle East (transfer of civilians into occupied territory), Bangladesh (unjustifiable delay in the repatriation of prisoners of war or civilians), and southern Africa (practices of apartheid) had directly influenced the inclusion at Article 85(4) of 'a strange collection of offences unrelated to one another'. ${ }^{52}$ Describing as 'remarkable' that Article 49 of the Fourth Geneva Convention should include a prohibition of the transfer of civilians into occupied territory 'only at para. 6 at the end', they note that the inversion of this position in the Additional Protocol is a practical experience in a specific case: the settlement of Israelis on the Golan Heights and the West Bank of Jordan. ${ }^{53}$

That criminal responsibility should accrue to individuals responsible for the transfer of civilians into occupied territory was restated at Article 22(2)(b) of the International Law Commission's $1991 \mathrm{draft}$ Code of Crimes against the Peace and Security of Mankind which declared that 'the establishment of settlers in an occupied territory

\footnotetext{
${ }^{50}$ Jean Pictet (ed.) Geneva Convention Relative To The Protection Of Civilian Persons In Time Of War (Geneva International Committee Of The Red Cross, 1958) at 283. A reflection of such sentiment may be seen in a General Assembly resolution of 1966 condemning 'as a crime against humanity, the policy of the Government of Portugal, which violates the economic and political rights of the indigenous population by the settlement of foreign immigrants in the Territories [under Portuguese administration] and by the exporting of African workers to South Africa.' UNGA res. 2184 (XXI) 1966 Question of territories under Portuguese administration, § 3.

${ }^{51}$ Sandoz, Commentary on the Additional Protocols of 8 June 1977 to the Geneva Conventions of 12 August $1949 \S 3504$.

${ }^{52} \mathrm{M}$. Bothe et al., New rules for victims of armed conflicts: commentary on the two 1977 protocols additional to the Geneva Conventions of 1949 (Martinus Nijhoff, 1982), at $517-518$.

${ }^{53}$ Ibid at 518.
} 
and changes to the demographic composition of an occupied territory' are an 'exceptionally serious war crime'. The Commentary states that: 'it is a crime to establish settlers in an occupied territory and to change the demographic composition of an occupied territory... Establishing settlers in an occupied territory constitutes a particularly serious misuse of power, especially since such an act could involve the disguised intent to annex the occupied territory. ${ }^{54}$

Article 20(c)(i) of the Commission's 1996 draft Code of Crimes against the Peace and Security of Mankind, also declared, without further commentary, that 'The transfer by the Occupying Power of parts of its own civilian population into the territory it occupies' is a war crime when committed wilfully in violation of international humanitarian law. ${ }^{55}$

\subsection{Negotiations at Rome}

Article 8(2)(b)(viii) of the Rome Statute sets forth the war crimes of 'transfer, directly or indirectly, by the Occupying Power of parts of its own civilian population into the territory it occupies, or the deportation or transfer of all or parts of the population of the occupied territory within or outside this territory.' Where William Schabas states that negotiation of the provision 'proved troublesome' due to Israeli opposition, he concludes that it was 'not very controversial, as it was well accepted by most delegations. ${ }^{56}$ Yoram Dinstein considers that the provision was the prime example of the 'controversial segments' of the definition of war crimes since, while Geneva Convention IV set deportation as a grave breach, the transfer of civilians into occupied territory was not. ${ }^{57}$ Knut Dörmann reports that the provision prompted 'the most difficult negotiations' at Rome, with agreement reached only after 'intensive informal negotiations which,

${ }^{54}$ UN Doc A/46/10 (1991) 2 YBILC 2, 105, para 7.

${ }^{55}$ Draft Code of Crimes against the Peace and Security of Mankind with commentaries 2 Year Book of the International Law Commission 2 (1996). The UN Transitional Administration in East Timor, in adopting Regulation No.2000/15 establishing panels with jurisdiction over serious criminal offences, affirmed at Section 6(1)(b)(viii) that 'the transfer, directly or indirectly, by the Occupying Power of parts of its own civilian population into the territory it occupies' constitutes a war crime in international armed conflicts. UNTAET/REG/2000/15 (6 June 2000).

${ }^{56}$ William Schabas, The International Criminal Court: A Commentary on the Rome Statute (OUP, 2010) 234.

${ }^{57}$ Y. Dinstein, The Conduct of Hostilities under the Law of International Armed Conflict (Cambridge: Cambridge University Press, 2004), at 232-233. 
due to the sensitivity of the issue, were almost exclusively conducted between interested delegations behind closed doors'. ${ }^{58}$ Academic commentaries on the drafting process at Rome are replete with similar, typically sparse, and frequently inconclusive observations as to the provision.

The war crime had been on the table from the informal texts of April 1996 under the subhead 'other serious violations of the laws or customs of war'. ${ }^{59}$ An August 1996 working paper draft statute submitted by France made no reference to the transfer of civilians into occupied territory, ${ }^{60}$ though it reappeared in a February 1997 working paper prepared by the ICRC and submitted by Switzerland and New Zealand. ${ }^{61}$ The provision was initially placed in square brackets as para 19(f) in informal working papers ${ }^{62}$ though the brackets were promptly dropped. ${ }^{63}$ A subsequent informal working paper included the option of deleting the provision, ${ }^{64}$ while a new formulation was proposed by Cyprus, Egypt, Greece, and Switzerland. ${ }^{65}$ This was included as option 3 in the Zutphen Draft Statute, that was to set the base for negotiations at Rome, and which provided for four options on sub-paragraph (f) ${ }^{66}$ :

Option1 The transfer by the Occupying Power of parts of its own civilian population into the territory it occupies;

${ }^{58}$ K. Dörmann, "War Crimes under the Rome Statute of the International Criminal Court, with a Special Focus on the Negotiations on the Elements of Crimes' 7 Max Planck YearBook of United Nations Law (2003) 341-407, at 395.

${ }^{59}$ Chairman's Informal Text No. 4 (4 April 1996), at 4; Proceedings of the Preparatory Committee during the Period 25 March-12 April 1996, A/AC.249/ CRP.9/Add.4 (11 April 1996), at 7.

${ }^{60}$ Working paper draft statute A/AC.249/L.3 (6 August 1996).

${ }^{61}$ A/AC.249/1997/WG.1/DP.2 (14 February 1997), at 2. And was again included in a draft consolidated text of the statute, with a footnote stating that 'This provision should be read together with article 49 of the Fourth Geneva Convention.' A/ AC.249/1997/WG.1/CRP.2 (20 February 1997), at 3-4.

${ }^{62}$ This was followed by a note to the effect that the UK believed 'square brackets should remain.' Informal working paper on war crimes (14 July 1997), at 2. https:// www.legal-tools.org/doc/7ba0b8/. A/AC.249/1997/WG.1/CRP.7 (3 December 1997), at 2 .

63 A/AC.249/1997/WG.1/CRP.8 (5 December 1997), at 2.

${ }^{64}$ Informal Working Paper on War Crimes (11 December 1997), at 3.

${ }^{65}$ A/AC.249/1997/WG.I/DP.22 (11 December 1997).

${ }^{66}$ Zutphen Draft A/AC.249/1998/L.13 (4 February 1998), at 23-24. 
Option2 The transfer by the Occupying Power of parts of its own civilian population into the territory it occupies, or the deportation or transfer of all or parts of the population of the occupied territory within or outside this territory;

Option3 (i) The establishment of settlers in an occupied territory and changes to the demographic composition of an occupied territory; (ii) The transfer by the Occupying Power of parts of its own civilian population into the territory it occupies, or the deportation or transfer of all or parts of the population of the occupied territory within or outside this territory;

Option 4 No paragraph (f).

The Summary Records of the meetings of the Committee of the Whole and of the Plenary Meetings through June 1998, while showing an even split between states favouring options $2,{ }^{67}$ or $3,{ }^{68}$ provide little insight to the debates. China leaned towards option 2, seeking the addition of the words 'which is not justified by the security of the population or imperative military reasons' after, 'into the territories it occupies'. ${ }^{69}$ Option 1 received less overt support, ${ }^{70}$ though the UK stated that it 'well understood the preference for options 2 and 3 but preferred option 1, because option 2 overlapped with the "grave breaches" provisions of the Geneva Conventions, which were in any event covered by section $\mathrm{A}$, and option 3 made new law. ${ }^{71}$ Japan also stated that sub-paragraph (f) 'should be included as it referred to a grave breach of Additional Protocol I', and that while flexible with regard to the options 'tentatively preferred option $1{ }^{1}{ }^{72}$

${ }^{67}$ Preference for option 2 was noted by Jordan, Costa Rica, Vietnam, Denmark, Sweden, Belgium (on the grounds that it exactly reproduced the text of article 85.4.a of Additional Protocol I), Russia, Brazil, Venezuela, Switzerland, Norway, Italy, Iran, and Senegal. (A/CONF.183/C.1/SR.4, (17 June 1998) §§ 47, 62, 69, 73, \& 75; A/ CONF.183/C1/SR.5 (18 June 1998) $\S 5,35,46,50,58,63,66,72, \& 83$ ).

${ }^{68}$ Preference for option 3 was noted by Syria, Libya, UAE, Greece, Kuwait, Lebanon, Korea, Saudi Arabia, Tunisia, Thailand, Egypt, Algeria, and Cuba. (A/ CONF.183/C.1/SR.4 (17 June 1998) §§ 44, 63, 66, \& 67; A/CONF.183/C1/SR.5 (18 June 1998) $\S \S 3,13,18,21,23,26,33,48, \& 69$.

${ }^{69}$ A/CONF.183/C.1/SR.4 (17 June 1998) $§ 65$. Proposal Submitted by China: Article 5 War Crimes, A/CONF.183/C.1/L.5 (18 June 1998). Also A/CONF. 183/C. 1/SR.33 (13 July 1998), § 40.

${ }^{70}$ Macedonia, Turkey, and Chile. A/CONF.183/C1/SR.5 (18 June 1998) $§ \S 60,70$, and 92 .

71 Ibid $\S 38$.

72 Ibid $\S 56$. 
As negotiations continued the United States indicated that subparagraph (f) 'should ideally not be included in the Statute', but that if it were, then the words 'directly or indirectly', not being drawn from Additional Protocol I, "should be deleted. ${ }^{73}$ This phrase had been added to the option 2 construction of the crime in a Bureau Discussion Paper dated 6 July 1998, the alternative options having been excised. ${ }^{74}$ The academic consensus is that the words were included as a result of wide support for the Arab Group's efforts to ensure clarity with regards to the acts or omissions of the occupying power with whom the crime is linked. ${ }^{75}$ According to Kittichaisaree, by this reading responsibility is to be attributed to an Occupying Power not only if it deliberately organizes the transfer of its own population into occupied territory, but also where it takes no effective steps to prevent its own population from organizing such a transfer'. ${ }^{76}$

Israel was the only state to steadfastly support the deletion of the provision, ${ }^{77}$ and 'particularly opposed' the reference to 'transfer directly or indirectly' on the grounds that it 'had no basis in customary international law. ${ }^{, 78}$ This opposition appears to have been primarily based on the 'indirect' aspect, which David Scheffer understood as having been an Egyptian inspired move 'to snare the Israeli practice of providing tax incentives to its citizens to move to the Israeli settlements on the West Bank and in Gaza, which most of the world regarded as occupied territory following the 1967 war'. ${ }^{79}$

Ultimately, option 2 of the Zutphen Draft, with the addition of the phrase 'directly or indirectly', was adopted as the first part of Article $8(2)(b)($ viii).

${ }^{73}$ A/CONF. 183/C. 1/SR.33 13 July 1998, § 26.

${ }^{74}$ A/CONF.183/C.1/L.53 Bureau: discussion paper regarding part 2 (6 July 1998). Further included at A/CONF.183/C.1/L.59 [incorporating A/CONF.J83/C. 1/L59/ Corr.I of 1 July 1998] Bureau: proposal regarding part 2 (10 July 1998).

${ }^{75}$ Also H. von Hebel, 'Article 8(2)(b)(viii)' in R.S. Lee (ed.), The International Criminal Court: Elements of Crimes and Rules of Procedure and Evidence (Transnational, 2001), at 159.

${ }^{76}$ K. Kittichaisaree, International Criminal Law (Oxford: Oxford University Press, 2001), at 168 .

${ }^{77}$ A/CONF.183/C1/SR.5, 18 June 1998, § 80.

${ }^{78}$ A/CONF.183/C.1/SR.27, 8 July 1998, § 32; A/CONF.183/C.1/SR.35, 13 July $1998, \S 25$.

${ }^{79}$ David Scheffer, All the Missing Souls: A Personal History of the War Crimes Tribunals (Princeton University Press, 2012), 205. 


\subsection{The Elements of Crimes}

The Elements of Crimes with respect Article 8(2)(b)(viii) adopted by the Assembly of States Parties in 2002 read:

1. The perpetrator: (a) Transferred, [FN 44: the term 'transfer' needs to be interpreted in accordance with the relevant provisions of international humanitarian law] directly or indirectly, parts of its own population into the territory it occupies; or (b) Deported or transferred all or parts of the population of the occupied territory within or outside this territory.

2. The conduct took place in the context of and was associated with an international armed conflict.

3. The perpetrator was aware of factual circumstances that established the existence of an armed conflict.

During negotiations, the US delegation at Prepcom sought to significantly raise the threshold for the commission of the war crime in order to allay 'fears' that (im)'permissible gloss' had been placed on Article 49(6) of Geneva Convention IV by the addition of the term 'directly or indirectly'. ${ }^{80}$ The US proposal, which does not appear to have received any support, would have required that the perpetrator 'intended to effect the compulsory transfer, on a large scale, of parts of the population of the Occupying Power into such occupied territory'. Additional elements of the proposal required that the perpetrator 'effected such transfer', 'intended that such transfer would endanger the separate identity of the local population in such occupied territory', and that 'the transfer worsened the economic situation of the local population and endangered their separate identity. ${ }^{81}$ Conversely, the Arab Group proposal sought to broaden the scope by spelling out what appear to be the applicable modes of liability: 'The perpetrator, directly or indirectly: (a) Induced, facilitated, participated or helped in any manner in the transfer of civilian population of the Occupying Power into the territory it occupies'. ${ }^{82}$

\footnotetext{
${ }^{80}$ R. Wedgwood, 'The International Criminal Court: An American view' 10 European Journal of International Law 1 (1999) 93, at 99; G. Hafner et al., 'A response to the American view as presented by Ruth Wedgwood' 10 EJIL 1 (1999) 108, at $120-121$.

${ }^{81}$ Proposal by the USA (PCNICC/1999/DP.4/Add.2). Japan had also proposed inclusion of a requirement that 'Such transfer or deportation was conducted in violation of article 49 of the Fourth Geneva Convention' (PCNICC/1999/WGEC/ DP.12).

${ }^{82}$ Proposal by Algeria, Bahrain, Egypt, Iraq, Jordan, Kuwait, Lebanon, the Libyan Arab Jamahiriya, Morocco, Oman, Qatar, Saudi Arabia, the Sudan, the
} 
The text as adopted was as initially proposed by Costa Rica, Hungary, and Switzerland: 'The perpetrator: (a) Transferred, directly or indirectly, parts of its own population into the territory it occupies. ${ }^{83}$ This text had been supplemented by an oral amendment proposed by Switzerland to include 'civilian' and 'of the Occupying Power' as found in Article 8 itself, so as to read: 'The Perpetrator: (a) Transferred, directly or indirectly, parts of the civilian population of the occupying power into the occupied territory it occupies'.

The Swiss intention had been to retain the reference to the occupying power as present in the Statute, rather than refer to the individual perpetrator only. According to von Hebel, this was rejected due to the Arab Group's concern that reference in the Elements to the Occupying Power might be interpreted as requiring some form of government involvement and thereby as limiting the scope of the provision. $^{\text {, }}{ }^{4}$

Strikingly, the Elements omit the word 'civilian' before 'population' as is found in the Statute, an omission which not Dörmann (or anyone else) can explain: 'Given that the substantive discussions were held among some interested delegations, it is not clear whether the omission was a conscious decision, and if so for what reason, or a mere drafting error. ${ }^{, 85}$ von Hebel notes that after a final compromise on the text had been reached in August 1999, Turkey made an informal suggestion to add the word 'civilian' in order to bring it in line with the Statute, yet the amendment as proposed, and the decisions to reject it, "were not exclusively based on grammatical reasons., 86

The final text also includes a footnote to the word 'transferred', noting that 'The term 'transfer' needs to be interpreted in accordance with the relevant provisions of international humanitarian law.' Dörmann surmised that the footnote 'states the obvious, without

Footnote 82 continued

Syrian Arab Republic, Tunisia, the UAE and Yemen (PCNICC/1999/WGEC/ DP.25).

${ }^{83}$ Proposal by Costa Rica, Hungary and Switzerland (PCNICC/1999/WGEC/ DP.8).

${ }^{84}$ von Hebel, 'Article $8(2)($ b)(viii)' at 161.

${ }^{85}$ Knut Dörmann et al., Elements of War Crimes Under the Rome Statute of the International Criminal Court: Sources and Commentary (Cambridge: ICRC, Cambridge University Press, 2003), at 209.

${ }^{86}$ von Hebel, 'Article 8(2)(b)(viii)' at 161, fn 81. 
giving any further clarification', ${ }^{87}$ and von Hebel, describing it as 'deliberately ambiguous', suggests that most states 'considered this additional wording as at most a clarification, not an extension of the scope of the relevant provisions. ${ }^{88}$ The footnote does appear redundant given that the Statute's Article 21 on applicable law provides that in 'second place', after the Statute itself, with its Elements of Crimes and Rules of Procedure and Evidence, are included as a source, 'the established principles of the international law of armed conflict'. ${ }^{89}$

Von Hebel considers the final text of the Elements to be grammatically incorrect - as clearly seen in the manner by which the paragraph seems to refer to the act of individual and of a state in the selfsame breath such that 'the perpetrator' transfers 'its own population' into the territory 'it occupies', where the 'it' in question relates to a state as an occupying power - and that it would have been preferable for the Swiss proposal to have been adopted with the inclusion of the oral amendment, ${ }^{90}$ a reasonable conclusion.

\subsection{Directly or Indirectly}

Regarding the inclusion of the phrase 'directly or indirectly', RS Lee queried whether 'In legal terms... this additional language has any significant impact'. ${ }^{91}$ As previously noted, the phrase has been understood as reaffirming that the responsibility of the occupying power for transfer may be triggered by acts or omissions. It also appears that the Arab Group understood the phrase as confirming, unnecessarily, that the Statute's various modes of liability apply also to this particular provision. One issue on which the phrase has been regarded as declarative, is the opinion that transfer of civilians encompasses both voluntary and forced transfer.

A page dated 2001 on Israel's Ministry of Foreign Affairs website claims that: 'International humanitarian law prohibits the forcible transfer of segments of the population of a state to the territory of

\footnotetext{
${ }^{87}$ Knut Dörmann, 'War Crimes Under the Rome Statute of the International Criminal Court, With a Special Focus on the Negotiations of the Elements of Crimes' Max Planck UNYB 7, at 395.

88 von Hebel, 'Article 8(2)(b)(viii)' at 159.

${ }^{89}$ Article 21.1.b ICCSt.

${ }^{90}$ von Hebel, 'Article 8(2)(b)(viii)' at 161.

${ }^{91}$ R.S. Lee, The International Criminal Court: The Making of the Rome Statute: Issues, Negotiations, Results (Leidin: Martinus Nijhoff, 1999), at 113.
} 
another state which it has occupied as a result of the resort to armed force. ${ }^{92}$ This contention, that humanitarian law prohibits only the forced transfer of civilians into occupied territory, finds little, if any, support. Kretzmer has noted that the International Court of Justice's rejection of suggestions that the term 'transfer' in Article 49(6) implies an element of coercion, was 'well-founded', on the basis that the object of the Fourth Geneva Convention 'is to protect civilians in the occupied territory and not the population of the occupying power', and that 'From the point of view of the protected persons, whether the transfer of outsiders into their territory is forcible or not would seem to be irrelevant. ${ }^{93}$ Dinstein, noting that 'A transfer entails movement of persons into an occupied territory with a view to settling there' stresses that where the first paragraph of Article 49 speaks of 'forcible transfers' the attachment 'forcible' is absent from the sixth, a point made even clearer in the Rome Statute, 'though strictly speaking no embellishment is required. ${ }^{94}$ In the Wall Advisory Opinion, the International Court of Justice stated that Article 49(6):

prohibits not only deportations or forced transfers of population such as those carried out during the Second World War, but also any measures taken by an occupying Power in order to organize or encourage transfers of parts of its own population into the occupied territory. In this respect, the information provided to the Court shows that, since 1977, Israel has conducted a policy and developed practices involving the establishment of Settlements in the Occupied Palestinian Territory, contrary to the terms of Article 49, paragraph $6 \ldots{ }^{95}$

With respect the war crime in the Rome Statute, the ICRC similarly understand that: "The inclusion of "indirect" indicates that the population of the occupying power need not necessarily be physically forced or otherwise compelled. Therefore, acts of inducement or

${ }^{92}$ Israel Ministry of Foreign Affairs, 'Israeli Settlements and International Law' 21 May 2001, at http://mfa.gov.il/MFA/ForeignPolicy/Peace/Guide/Pages/Israeli\% 20Settlements\%20and\%20International\%20Law.aspx.

${ }^{93}$ David Kretzmer, 'The Advisory Opinion: The Light Treatment of International Humanitarian Law' 99 AJIL 88 (2005), at 91. Also Kittichaisaree, International Criminal Law at 169: Michael Cottier, 'Article 8 War Crimes: para 2b (xviii)' in Triffterer (ed.), Commentary on the Rome Statute of the International Criminal Court: Observer's Notes, Article by Article (Baden-Baden: Nomos Verlagsgellschaft, 1999), at 214; Dörmann et al., Elements of War Crimes Under the Rome Statute at 211.

${ }^{94}$ Yoram Dinstein, The International Law of Belligerent Occupation (Cambridge: Cambridge University Press, 2009), at 239-240.

95 The Wall Advisory Opinion $\S 120$. 
facilitation may fall under this war crime. ${ }^{96}$ Cottier agreed with the ICRC conclusion, noting that while "this has probably been the view of the great majority of States in regard to the prohibition under the law of the Geneva Conventions and Protocols, a few States have been of the opposite view. The addition of "directly or indirectly" serves to clarify this point. ${ }^{97}$

\section{RESPONSIBILITY OF ISRAEL AS AN OCCUPYING POWER}

Given the rationale underlining the criminalization of the transfer of civilians into occupied territory, this war crime may only be perpetrated in the context of an international armed conflict. As reaffirmed in the Wall Advisory Opinion, the territory situated between the Green Line and the former eastern boundary of Mandate Palestine, as well as the Gaza Strip, has been subject to military occupation by Israel since 1967: 'Subsequent events in these territories ... have done nothing to alter this situation. All these territories (including East Jerusalem) remain occupied territories and Israel has continued to have the status of occupying Power. ${ }^{98}$

Given the reference to an occupying power, the war crime can be understood also as a type of 'crime' of state. It is not dissimilar to the Statute's crime of aggression, yet in several respects it closer resembles the concept of a crime against humanity. Schabas observed that

\footnotetext{
${ }^{96}$ Annex I: Paper prepared by the ICRC on article 8, paragraph 2 (b), (viii), (x), (xiii), (xiv), (xv), (xvi), (xxi), (xxii) and (xxvi), of the Statute of the ICC, PCNICC/ 1999IWGECIINF.2 (14 July 1999), at 13.

${ }^{97}$ Cottier 'Article 8 War Crimes: para 2b (xviii)' at 214.

98 The Wall Advisory Opinion $\S 78$; On occupation see S. Darcy and J. Reynolds, 'An Enduring Occupation: The Status of the Gaza Strip from the Perspective of International Humanitarian Law' 15 Journal of Conflict and Security Law 2 (2010) 211. A footnote to the Elements of Crimes, accompanying the requirement under Article 8(2)(a), that 'The conduct took place in the context of and was associated with an international armed conflict', states that 'The term 'international armed conflict' includes military occupation.' The footnote continued to state that this 'also applies to the corresponding element in each crime under article 8(2)(a).' Since the Elements to each of the paragraph (2)(b) crimes include the selfsame element, the failure of the footnote to clarify its application thereto is likely a result of inadequate drafting. As noted by Schabas 'There is no evidence in the travaux préparatoires that a distinct definition of armed conflict applicable to article 8(2)(b) was ever considered.' W. Schabas, The International Criminal Court: A Commentary on the Rome Statute (Oxford: Oxford University Press, 2010), at 203.
} 
the language of the chapeau to Article 8, 'that the court shall have jurisdiction in respect of war crimes when committed as part of a plan or policy or as part of a large-scale commission of such crimes', had in general terms aligned war crimes more closely with crimes against humanity, ${ }^{99}$ and the provision here seems emblematic of Cherif Bassiouini's remark that 'Crimes against humanity and genocide are essentially crimes of state, as are sometimes war crimes, because they need the substantial involvement of state organs, including the army, police, paramilitary groups, and the state's bureaucracy'. ${ }^{100}$

The general rule on state responsibility for internationally wrongful acts is that 'the only conduct attributed to the State at the international level is that of its organs of government, or of others who have acted under the direction, instigation or control of those organs, i.e. as agents of the State. ${ }^{101}$ In the Wall Advisory Opinion, the International Court of Justice cited with approval UN Security Council resolution 446 (1979) calling upon 'Israel, as the occupying Power, to abide scrupulously' by Geneva Convention IV and 'not to transfer parts of its own civilian population into the occupied Arab territories'. The Court also referred to Security Council resolution 465 (1980) which described 'Israel's policy and practices of settling parts of its population and new immigrants in [the occupied] territories' as a 'flagrant violation' of the Convention. ${ }^{102}$ Affirmation of the illegality of Israel's settlement policy and practice has been widespread, repetitive, and consistent. The legal opinion of the US State Department on Israel's settlement policy, as stated in 1978, was that 'the establishment of the civilian settlements in those territories is inconsistent with international law. ${ }^{103}$ The Conference of the High

\footnotetext{
${ }^{99}$ W. Schabas, An Introduction to the International Criminal Court (3rd edn., Cambridge: Cambridge University Press, 2007), at 117.

100 M.C. Bassiouni, 'The Normative Framework of International Humanitarian Law' in Bassiouni (ed.), International Criminal Law: Sources, Subjects and Contents (3rd edn., Martinus Nijhoff, 2008), at 495; W. Schabas, 'State Policy as an Element of International Crimes' 98 Journal of Criminal Law \& Criminology (2007-2008), 953982.

101 Article 4. International Law Commission Report, A/56/10, 2001.

102 The Wall Advisory Opinion $\S 120$. Also Opinion of Israeli Ministry of Foreign Affairs Legal Adviser Theodor Meron on settlements in the Occupied Territories', 18 September 1967, available athttp://www.soas.ac.uk/lawpeacemideast/resources/ file48485.pdf.

103 'Letter of the State Department Legal Advisor, Herbert J. Hansell, Concerning the Legality of Israeli Settlements in the Occupied Territories' 17 International Legal Materials (1978), at 777-779.
} 
Contracting Parties to the Fourth Geneva Convention and the Council of the European Union ${ }^{104}$ reaffirmed the illegality of the settlements in the said territories and of the extension thereof., ${ }^{, 105}$

Military occupation of foreign territory is perhaps the ultimate manifestation of the state's exercise of public authority, primarily through its military organs, but also through the legislative, executive, and judicial branches. Article 3 of Hague Convention IV of 1907 provides that a belligerent party 'shall be responsible for all acts committed by persons forming part of its armed forces', ${ }^{106}$ while Article 91 of Additional Protocol 1 ensures that a party to the conflict 'shall be responsible for all acts by persons forming part of its armed forces'. ${ }^{107}$

In the Armed Activities Case, the International Court of Justice, having concluded that Uganda was an occupying power in Ituri, the Democratic Republic of the Congo, found that:

Uganda's responsibility is engaged both for any acts of its military that violated its international obligations and for any lack of vigilance in preventing violations of human rights and international humanitarian law by other actors present in the occupied territory, including rebel groups acting on their own account.

The Court notes that Uganda at all times has responsibility for all actions and omissions of its own military forces in the territory of the DRC in breach of its obligations under the rules of international human rights law and international humanitarian law which are relevant and applicable in the specific situation. ${ }^{108}$

In the section on Palestine in its November 2015 Report on Preliminary Examination Activities, the ICC's Office of the Prosecutor noted under 'Alleged Crimes' that 'Successive Israeli governments have allegedly led and directly participated in the planning, con-

104 Press Release, 17438/1/12 REV 1 (10 December 2012), at 7.

105 Annexe 1: Conference of High Contracting Parties to the Fourth Geneva Convention, Declaration, Geneva, 5 December 2001, § 12; See also B. Watts, 'Better than a Thousand Hollow Words Is One Word that Brings Peace: Enforcing Article 49(6) of the Fourth Geneva Convention Against Israeli Settlements in the Occupied Palestinian Territory' 24 Pacific McGeorge Global Business and Development Law Journal (2011), at 451-452.

${ }^{106}$ Convention (IV) respecting the Laws and Customs of War on Land and its annex: The Hague, 1907.

${ }^{107}$ M. Sassòli, 'State Responsibility for Violations of International Humanitarian Law' International Review of the Red Cross 84 (2002) 846, at 405.

108 ICJ, Armed Activities on the Territory of the Congo (Democratic Republic of the Congo $v$. Uganda) $2005 \S \S 179-180$. 
struction, development, consolidation and/or encouragement of settlements on West Bank territory' and that 'settlement activity is allegedly created and maintained through deliberate implementation of a carefully conceived network of policies, laws, and physical measures. ${ }^{109}$ While merely a preliminary document, the Report's emphasis on alleged acts of state officials reflects the idea that it is not individual settlers who would be the subject of ICC proceedings concerning the war crime of transfer of civilians, but that individuals in positions of power (likely including certain settlers), those most responsible for planning and implementing the overall policy of transfer, who are likely to be identified as individually criminally responsible.

The substance of two reports commissioned by Israeli governments concerning settlements not 'officially' authorized by the state illustrate the nature of the occupying power's acts and omissions relating to the transfer of civilians into occupied territory. Talia Sasson's 2005 Report, while eschewing consideration of 'authorised' settlements or of international law, found:

the main relevant authorities involved in the matter of unauthorized outposts are the Ministry of Defense and the IDF, including the Civil Administration; the Ministry of Construction \& Housing; the Settlement Division of the World Zionist Organization; the Ministry of Interior Affairs. ... Nevertheless, other bodies are involved in establishing the unauthorized outposts, including the aerial councils in Judea, Samaria and Gaza, and other governmental ministries. ${ }^{110}$

Sasson found that the state had 'officially acknowledged and encouraged the settlement enterprise', until policy changed in the 1990s:

The Israeli governments were no longer officially involved in the establishment of settlements, apparently due to Israel's international situation, and the negative position of most nations towards the settlement enterprise. That was not the case for public authorities and other Israeli government bodies, who took, along with others, a major role in establishing the unauthorized outposts. Some of which were inspired by the political echelon, sometimes by over-

${ }^{109}$ ICC Office of the Prosecutor, Report on Preliminary Examination Activities (2015) para 68.

${ }^{110}$ T. Sasson, 'Summary of the Opinion Concerning Unauthorized Outposts' (10 March 2005), Section C, available online at: http://www.mfa.gov.il/MFA/Govern ment $/$ Law/Legal + Issues + and + Rulings/Summary + of + Opinion + Concerning + Unauthorized + Outposts + - + Talya + Sason + Adv.htm . 
looking, sometimes by actual encouragement and support, but never as a result of an authorized resolution by the qualified political echelon of the State. ${ }^{111}$

The Sasson Report, approved but not implemented by the Israeli government, was followed by the 2012 Levy Report of 'The Commission to Examine the Status of Building in Judea and Samaria'. Variously received as a 'travesty', ${ }^{112}$ and 'an ethical obstruction' for its treatment of the rule of law, ${ }^{113}$ the Levy Report asserted that the law of occupation 'cannot be considered applicable', and that the provisions of the Fourth Geneva Convention 'were never intended to apply to the type of settlement activity carried out by Israel. ${ }^{114}$ In considering attribution of responsibility for acts to the state, a pertinent excerpt is the Report's affirmation that:

\begin{abstract}
With regard to settlements established in Judea and Samaria [the occupied West Bank] on state lands or on land purchased by Israelis with the assistance of official authorities such as the World Zionist Organization Settlements Division and the Ministry of Housing, and which have been defined as 'unauthorized' or 'illegal' due to the fact that they were established without any formal government decision, our conclusion is that the establishment of such settlements was carried out with the knowledge, encouragement and tacit approval of the most senior government level - government ministers and the Prime Minister, and therefore such conduct is to be seen as implied agreement. ${ }^{115}$
\end{abstract}

Regarding 'unofficial' settlement 'outposts', Israel's state responsibility for transfer is triggered, whether by covert approval as documented above, or by overt and indispensable action in having the Israeli military assist, enable, and protect those civilians being transferred into occupied territory. The HRC's 2013 Fact-Finding Mission Report was alert to subterfuge on the part of the Israeli state,

${ }^{111}$ Ibid at Section $\mathrm{H}$.

${ }^{112}$ Iain Scobbie, 'Justice Levy's Legal Tinsel: The Recent Israeli Report on the Status of the West Bank and Legality of the Settlements' EJIL: Talk! Blog of the European Journal of International Law, 6 September 2012.

113 Orna Ben-Naftali \& Rafi Reznik, The Astro-Nomos: On International Legal Paradigms and the Legal Status of the West Bank 14 Washington University Global Studies Law Review 3 (2015).

${ }^{114}$ Report of The Commission to Examine the Status of Building in Judea and Samaria: Conclusions and Recommendations (March 2012), at 1, available at http:// unispal.un.org/UNISPAL.NSF/0/D9D07DCF58E781C585257A3A005956A6. The full Report, in Hebrew, at: http://www.pmo.gov.il/Documents/doch090712.pdf.

115 Ibid at p. 3. 
noting that 'Government investment in the settlements has not been made explicit in the Public Budget, but allocated through hidden provisions in a process that has been described as "partially secretive" and "a political tool". ${ }^{116}$ The Report concluded that "the State of Israel has had full control of the settlements in the OPT since 1967 and continues to promote and sustain them through infrastructure and security measures. 117

\section{TEMPORALITY AND TRANSFER}

Addressing the Assembly of State Parties to the Rome Statute in December 2014, Palestine's ambassador asked: 'If the Rome Statute states that 'the transfer, directly or indirectly, by the Occupying Power of parts of its own civilian population into the territory it occupies' is a war crime, then, in the case of illegal Israeli settlements and settlers in our occupied land, isn't it logical to go to the ICC so as to prosecute and bring an end to this ongoing war crime and to prosecute this continuing crime? ${ }^{118}$

Andreas Zimmermann opposed the idea that the transfer of civilians is a continuing war crime rather than an instantaneous war crime: 'As a matter of fact, once settlers have already been settled in an occupied territory, their transfer has been completed even if they then continue to be induced [by state incentives] to stay in such territory. ${ }^{119}$ Such a conclusion was said to have been 'confirmed by the drafting history of the norm' and specifically the decision not to have incorporated option 3(1) of the Zutphen Draft into the Statute. Zimmermann interpreted the phrase 'the establishment of settlers in an occupied territory' in the draft as 'hinting at an ongoing and continuous character', a meaning then, which was to be denied to the term 'transfer' as finally adopted. ${ }^{120}$

\footnotetext{
116 Supra, note 19, §§ 18-30, 20.

117 Ibid $\S 100$.

${ }^{118}$ Statement by Dr Riyad Mansour, Ambassador, Permanent Observer Mission of the State of Palestine to the United Nations before the Assembly of States Parties to the Rome Statute of the International Criminal Court (thirteenth session), General Debate, New York, 15 December 2014.

${ }^{119}$ Andreas Zimmermann, 'Palestine and the International Criminal Court Quo Vadis? Reach and Limits of Declarations under Article 12(3)' 11 JICJ (2013) 303, at 324.
}

${ }^{120}$ Ibid. 
International criminal law on the scope and nature of continuing crimes does not support such a restrictive opinion. Judge Shahabuddeen, dissenting from a three to two majority decision of the ICTR Appeal Chamber in 2008 that direct and public incitement to genocide was not a continuing crime, but, 'is completed as soon as the discourse in question is uttered or published', ${ }^{121}$ remarked 'There is not much authority in the field. This no doubt is why the judgement of the Appeals Chamber has cited no cases in support of its conclusion. ${ }^{122}$ In 2012, and also in a dissenting opinion, Judge Cançado Trindade at the ICJ noted that 'although the notion of continuing situation has roots in the international legal thinking of as early as the first half of the twentieth century, it has passed almost unnoticed, and remains virtually unexplored, in doctrinal writings to date, in public international law. ${ }^{123}$

The subject has been addressed by the ICC on several occasions, and can be understood as comprising two distinct yet often overlapping concepts. The first concerns the Court's temporal jurisdiction and whether a crime such as the transfer of civilians into occupied territory, commenced prior to the Statute's entry into force, continues in such a manner that the Court has the power to investigate and prosecute (i.e. continuing crimes). The second concerns how the Court views ongoing conduct characterised by the serial repetition of discrete acts over a prolonged period of time (i.e. continuous crimes.)

At the ICC's Pre Trial Chamber, Judge de Gurmendi considered the majority's reasoning with respect to 'ongoing and continuing crimes' to have been too narrow in the context of the Prosecutor's suggestion that the Chamber might decide to extend the temporal scope of the investigation in Côte d'Ivoire. This was so even despite the majority having accepted that crimes committed prior to or after the date of the Prosecutor's application were covered by the grant of authorisation so long as they 'at least in a broad sense, involve the same actors, and have been committed within the context of the same attacks (crimes against humanity) or the same conflict (war

${ }^{121}$ Nahimana et al. v The Prosecutor, ICTR-99-52-A, 28 November 2007, § 723.

122 Nahimana et al. v The Prosecutor, ICTR-99-52-A, 28 November 2007. Partly Dissenting Opinion of Judge Shahabuddeen $\S 23$.

${ }^{123}$ Jurisdictional Immunities of the State (Germany v. Italy: Greece intervening) Judgment of 3 February 2012, Dissenting opinion of Judge Cançado Trindade, $\S 72$. Also, Questions relating to the Obligation to Prosecute or Extradite (Belgium v. Senegal), Judgement of 20 July 2012, 145-153. 
crimes). ${ }^{124}$ While finding it inappropriate that the Prosecutor was required to revert to the Chamber with further information in order to investigate other crimes committed prior to the dates within the grant of authorization, de Gurmendi held that "examples of continuing crimes under the Statute include those of enforced disappearance of persons, enslavement, imprisonment, or other severe deprivation of physical liberty, sexual slavery, enforced prostitution, persecution and the crime of apartheid. ${ }^{125}$

\subsection{Continuing Crimes}

Mohamed El Zeidy's analysis as to whether the ICC could prosecute crimes that commenced prior to the Statute's entry into force and which continue thereafter, notes that the issue was raised during negotiations at Rome but was left for the Court itself to resolve. ${ }^{126}$ During drafting of the Elements a footnote was added to Article 7(1)(i) on enforced disappearances as a crime against humanity: 'This crime falls under the jurisdiction of the Court only if the attack referred to in elements 7 and 8 occurs after the entry into force of the Statute.' El Zeidy concludes that since the drafters' intentions were directed and restricted to this crime, then the ICC 'may not be barred from applying the doctrine and exercising jurisdiction over any other crime of the same nature' and that the Court is 'barred only from looking at completed crimes committed before the Statute's entry into force as opposed to continuing crimes. ${ }^{, 127}$

Such an approach was shared by Judge Pocar, also dissenting in the Nahimana Appeal in a comment which illustrates the overlap

${ }^{124}$ Situation in Cote d'Ivoire Decision Pursuant to Article 15 of the Rome Statute on the Authorisation of an Investigation into the Situation in the Republic of Côte d'Ivoire ICC-02/11-14, 3 October 2011, § 179-180.

${ }^{125}$ Situation in Cote d'Ivoire Judge Fernandez de Gurmendi's separate and partially dissenting opinion to the Decision Pursuant to Article 15 of the Rome Statute on the Authorisation of an Investigation into the Situation in the Republic of Cote d'Ivoire ICC-02/11-15, 3 October 2011, § 69.

${ }^{126}$ Mohamed M El Zeidy, 'The Ugandan Government Triggers the First Test of the Complementarity Principle: An assessment of the First State's Part Referral to the ICC' 5 International Criminal law Review (2005) 83, 91. Also Stahn, El Zeidy, \& Olásolo, The International Criminal Court's Ad Hoc Jurisdiction Revisited 99 AJIL (2005) 421-431.

${ }^{127}$ El Zeidy, 'The Ugandan Government Triggers the First Test of the Complementarity Principle' at pp 92-99. CF Machteld Boot, Genocide, Crimes Against Humanity, War Crimes: Nullum Crimen Sine Lege and the Subject Matter Jurisdiction of the International Criminal Court (Intersentia, 2002) at 371. 
between continuing and continuous crimes. Disagreeing with the Chamber's finding that the drafters had 'intended to exclude from the Statute's temporal scope a crime of which certain material elements were committed prior to 1 January 1994', Pocar wrote: 'I am not convinced that it is correct to hold that a conviction can be based solely on that part of the criminal conduct which took place in 1994. In so far as offences are repeated over time and are linked by a common intent or purpose, they must be considered as a continuing offence, that is a single crime.'

The ICC's 2012 Judgment in Lubanga, citing the Nahimana Appeal Chamber's understanding of a continuing crime as one which 'implies an ongoing activity', ${ }^{129}$ followed the approach taken by the Pre Trial Chamber in 2006 and 2007, and by the Special Court for Sierra Leone in the 2007 AFRC and 2012 Taylor judgments, ${ }^{130}$ that 'the crime of enlisting and conscripting [of child soldiers] is an offence of a continuing nature - referred to by some courts as a "continuous crime" and by others as a "permanent crime". ${ }^{131}$ The Trial Chamber confirmed that "the offences of conscripting and enlisting are committed at the moment a child under the age of 15 is enrolled into or joins an armed force or group, with or without compulsion. [...] These offences are continuous in nature. They end only when the child reaches 15 years of age or leaves the force or group., ${ }^{132}$

Rod Rastan, in contrasting the Statute's treatment of enforced disappearances perpetrated prior to its entry into force, and the $\mathrm{Lu}$ banga Chamber's approach to enlistment and conscription of child

${ }^{128}$ Nahimana et al. v The Prosecutor ICTR-99-52-A 28 November 2007. Partly Dissenting Opinion Of Judge Fausto Pocar $\S 2$.

${ }^{129}$ Situation in the Democratic Republic of The Congo in the Case of the Prosecutor v Thomas Lubanga Dyilo ICC-01/04-01/06 (14 March 2012) § 618 citing Nahimana AC § 721.

${ }^{130}$ The Special Court for Sierra Leone in the AFRC judgment recognized sexual slavery, child enlistment and conscription, and enslavement as constituting "prolonged offences or offences of a continuous nature' SCSL-04-16-T, 20 June 2007, § 39 $\& 1820$. The Court in the Taylor judgment also approved of the approach taken with respect conscription and enlistment of children in TC Lubanga Confirmation of Charges, SCSL-03-01-T, 26 April 2012, § 443.

${ }^{131}$ Situation in the Democratic Republic of The Congo in the Case of the Prosecutor v Thomas Lubanga Dyilo, ICC-01/04-01/06 (29 January 2007) § 248.

${ }^{132}$ Situation in the Democratic Republic of The Congo in the Case of the Prosecutor v Thomas Lubanga Dyilo ICC-01/04-01/06 (14 March 2012) § 618; Situation in the Democratic Republic of The Congo in the Case of the Prosecutor $v$ Thomas Lubanga Dyilo (29 January 2007) ICC-01/04-01/06 §§ 247-248. 
soldiers as continuing crimes, notes that while the elements of the former constitute a series of cumulative acts - detention, abduction, and denial - the requisite element of the latter is singular, such that 'the essence of the prohibition' is not merely the original recruitment as 'a discrete event in time' but equally the 'continued membership', even if commenced prior to the Court's temporal threshold. ${ }^{133}$

As a discrete criminal act, a clear parallel can be drawn between the crimes of enlistment and conscription of children as addressed in Lubanga and the crime of transfer of civilians into occupied territory. It is no stretch to assert such that the latter should also be recognised as a continuing crime, committed at the moment parts of the civilian population are transferred into occupied territory and perpetuated until such time as the civilians leave the occupied territory.

By this reading, which also serves the legal values of opposition to colonialism and the prerogative that occupation be temporary which lie behind the criminalization of the practice of transfer, one can readily argue that any transfer committed from the time the crime became a matter of customary law has continued in full such that the individuals responsible for the original transfer as well as the individuals responsible for maintaining the presence of those civilians transferred into prior to, and present in, occupied territory from June 2014 are liable to ICC prosecution.

\subsection{Continuous Crimes}

Rastan concluded with respect to Lubanga and the enlistment and conscription of child soldiers, that 'Strictly speaking, this is less a continuing crime, but more an extension of the idea of repeat acts that have their origin before the entry into force of the Rome Statute. ${ }^{134}$ This is also the case with respect to the transfer of civilians into occupied territory, since given the situation in Palestine, the evidence will show that the vast majority of settlers will have returned to Israel and been transferred back into occupied territory on numerous occasions since June 2014. The very purpose of the settlement project as a colonial enterprise is to fully incorporate the settlements and settlers into the state of Israel, a policy which provides the basis for the charge of apartheid by its exclusion and domination of Palestinians, and effected by Israel's claims to have

${ }^{133}$ Rod Rastan, 'Relationship to Domestic Jurisdiction' in Carsten Stahn (ed.) The Law and Practice of the International criminal Court (OUP, 2015) at 173.

${ }^{134}$ Rastan, 'Relationship to Domestic Jurisdiction' at 173. 
annexed certain occupied territory. The project itself, and the transfer of civilians in particular, is most accurately understood not as an 'event', but as a structural pursuit of a specific end point, namely the erasure of the distinction between colony (occupied territory) and metropole (Israel). ${ }^{135}$

The social and physical infrastructure embedding settlements with Israel is such that one cannot properly conceive of transfer solely in the manner as suggested by Zimmermann since the movement of individual Israeli civilians to and from occupied territory is an act repeated on a regular and ongoing basis. Judge de Gurmendi had noted that a "restrictive definition of "continuous crimes", or delictum continuatum, includes only those crimes involving a multiplicity of individual acts of the same perpetrator, each of them satisfying the legal elements of crimes of similar kind, which should be treated as only one act as a result of their tight internal and external connection'. ${ }^{136}$ A similar approach to continuous offences, "where each act in a series of separate but closely related acts fulfils all the elements of a certain criminalisation' had been suggested by Judge Pavel Dolenc at the ICTR: it is possible to regard the entire transaction, or series of repeated crimes, as a single crime. For these acts to be joined together, certain linking elements should be taken into account, such as the repetition of the same kind of crimes, the uniformity of the perpetrator's intent, the proximity in time between the acts, the location, the victim or class of victims, the object or purpose, and the opportunity. ${ }^{137}$

The multiplicity of similar acts constituting the transfer of parts of Israel's civilian population into occupied territory should be similarly constructed as a continuous crime in the case of individuals prosecuted under Article 8(2)(b)(viii). In 2007 the Lubanga Pre Trial Chamber ${ }^{138}$ held that while each instance of individual enlistment or

${ }^{135}$ Patrick Wolfe, Settler Colonialism and the Transformation of Anthropology: The Politics and Poetics of an Ethnographic Event (London: Cassell, 1999) at 163.

${ }^{136}$ Situation in Cote d'Ivoire Judge Fernandez de Gurmendi's separate and partially dissenting opinion to the Decision Pursuant to Article 15 of the Rome Statute on the Authorisation of an Investigation into the Situation in the Republic of Cote d'Ivoire ICC-02/11-15, 3 October 2011, § 44.

${ }^{137}$ The Prosecutor v. Laurent Semanza, ICTR-97-20-T, Separate and Dissenting Opinion of Judge Pavel Dolenc, 15 May 2003, § 32.

${ }^{138}$ Situation in the Democratic Republic of The Congo in the Case of the Prosecutor v Thomas Lubanga Dyilo, ICC-01/04-01/06 (29 January 2007) § § 248. A restatement of the holding in Decision on the Prosecution's application for a warrant of arrest, Article 58, ICC-01/04-01/07, (10 February 2006). 
conscription into a national armed force or armed group or use to participate actively in hostilities of children under the age of fifteen was recognized as constituting a crime within the jurisdiction of the Court, 'the Chamber considers that it is advisable to treat (1) all instances of enlistment into a national armed force or armed group, (2) all instances of conscription into a national armed force or armed group, and (3) all instances of use to participate actively in hostilities of children under the age of fifteen years, as a continuous war crime'. ${ }^{139}$

Given the parallels between patterns of crimes addressed in $\mathrm{Lu}$ bang $a$ and the patterns of transfer of civilians into occupied territory, it seems appropriate that the prosecution of an alleged perpetrator, aligned with and responsible for the implementation of the policy of transfer of civilians, be similarly based on each instance of transfer cumulatively presented as a continuous crime.

\section{CONCLUSION}

The Palestine section of the ICC Office of the Prosecutor's 2015 Report on Preliminary Examinations, under subhead 'Alleged crimes by IDF', reflects the tendency to consider 'settlement activity' through the exclusive lens of state responsibility. One should not, perhaps, be overly sensitive to a document which serves quite an indeterminate function, and which stresses that its descriptions 'should not be taken as indicative of or implying any particular legal qualifications or factual determinations'. Nonetheless, in light of the centrality of settlement and of transfer to ongoing widespread and systematic human rights abuses under occupation, it is insufficient that, rather than address the transfer of civilians into occupied territory as a war crime, the Report merely refers to 'a scheme of subsidies and incentives to encourage migration to the settlements'. ${ }^{140}$ The destruction and confiscation of land and property, the repression of the right to self-determination, and the implementation of an apartheid system are both the pre-condition for and the consequence of the overall settlement policy. Still, the Report chose to refer to 'migration' to describe the conduct criminalised in Article 8(2)(b)(viii)

${ }^{139}$ Situation in the Democratic Republic of The Congo in the Case of the Prosecutor v Thomas Lubanga Dyilo, PTC ICC-01/04-01/06-1-US-Exp-Corr., § 105.

${ }^{140}$ ICC Office of the Prosecutor, Report on Preliminary Examination Activities (2015) § 68. 
rather than apply the Statute's terminology of 'transfer'. Having provided an overview of the nature, scope, and purpose of the war crime in the context of the situation in Palestine, and confident in concluding that this crime can be investigated and prosecuted with adequate clarity and certainty, what remains remarkable is the absence of direct reference to, or acknowledgement of, the crime: It does not, for example, feature in the OTP's examples of crimes which have 'been traditionally under-prosecuted'. ${ }^{141}$ The centrality of the war crime to the consolidation of the occupation was clearly affirmed by Israel's explanation of its vote against the adoption of the Rome Statute. Appropriate labelling of criminal conduct is a perennial concern of international criminal law, and while the situation in Palestine encompasses a particularly broad range of international crimes, it cannot continue to be the case that a crime which goes to the core of this situation remains unspoken.

\section{OPEN ACCESS}

This article is distributed under the terms of the Creative Commons Attribution 4.0 International License (http://creativecommons.org/ licenses/by/4.0/), which permits unrestricted use, distribution, and reproduction in any medium, provided you give appropriate credit to the original author(s) and the source, provide a link to the Creative Commons license, and indicate if changes were made.

${ }^{141}$ Office of the Prosecutor, 'Policy Paper on Case Selection and Prioritisation' (15 September 2016) $\S 46$. 